\title{
Effect of Boron Foliar Application on Reproductive Growth of Sunflower (Helianthus annuus $\mathrm{L}_{\text {.) }}$
}

\author{
M. M. Al-Amery, ${ }^{1}$ J. H. Hamza, ${ }^{2,3}$ and M. P. Fuller ${ }^{3}$ \\ ${ }^{1}$ Biology Department, College of Science for Women, Baghdad University, Baghdad, Iraq \\ ${ }^{2}$ Agronomy Department, College of Agriculture, Baghdad University, Baghdad, Iraq \\ ${ }^{3}$ School of Biomedical and Biological Sciences, Faculty of Science and Technology, University of Plymouth, Plymouth PL4 8AA, UK \\ Correspondence should be addressed to M. P. Fuller, mfuller@plymouth.ac.uk
}

Received 27 March 2011; Revised 23 August 2011; Accepted 23 August 2011

Academic Editor: M. Tejada

Copyright ( $) 2011$ M. M. Al-Amery et al. This is an open access article distributed under the Creative Commons Attribution License, which permits unrestricted use, distribution, and reproduction in any medium, provided the original work is properly cited.

A study was carried out to determine the response of open pollinated sunflower (Helianthus annuus L. cv. Shumos) to boron fertilizer. Spring and autumn grown plots were sprayed with boron $\left(0,50,100,150,200\right.$, and $\left.250 \mathrm{mg} \mathrm{L}^{-1}\right)$ in a randomized complete block design. The results showed that boron and green Leaf area/LAI measured at the end of seed filling were linearly related in the spring crop. In the autumn crop, the relationship between boron and dry matter yield was linear, and applications above $100 \mathrm{mg} \mathrm{L}^{-1}$ significantly increased dry matter compared to the control. For the autumn crop, 100, 200, and $250 \mathrm{mg} \mathrm{L}^{-1}$ significantly increased seed number compared to the control, but only the $150 \mathrm{mg} \mathrm{L}^{-1}$ treatment increased seed weight significantly. Boron tended to decrease the empty seed percentage, and for the spring crop, this was incremental and linear with applications above $150 \mathrm{mg} \mathrm{L}^{-1}$ leading to significant reductions in empty seed percentage. Seed yield increased linearly in the autumn crop in response to boron, and 200 and $250 \mathrm{mg} \mathrm{L}^{-1}$ applications gave significant increases in yield compared to the control.

\section{Introduction}

Sunflower is the third most important oilseed crop in the Middle East after soybean and palm oil and has diverse markets for both oilseed and nonoilseed use including both as a bird food and as a human snack food [1]. Commercial sunflower production in Iraq is currently less than expected because of a variety of reasons including, suboptimal agricultural practices especially in regard to soil management and damage caused by bird attack either at sowing, germination, or flowering stages. Two sowing seasons are commonly used in Iraq, spring (for summer harvest) and summer (for autumn harvest) with a slightly higher yield potential associated with spring sowing due to more suitable growing temperatures. High temperatures at flowering and seed formation stages leads to pollen death and decreased seed fertility, and empty seed can form a high percentage at maturity exceeding $50 \%$ in some cultivars $[2,3]$. Sunflower pollination is best performed by insects and in commercial fields honeybees are reported to be the most suitable pollinating vectors $[2,3]$. Even under optimal honeybee activity in nonoilseed sunflower crops relatively large proportions $(15-50 \%)$ of seeds can remain empty. The same problem has also been found in oilseed sunflowers but on a smaller scale [4].

Empty seeds are primarily located in the proximal (central) and distal (peripheral) regions of the capitulum [4]. It has been suggested that the empty seeds result from several unrelated factors including boron deficiency. Boron deficiency symptoms usually appear on leaves, stems, and reproductive parts [5-7] eventually manifesting as stem corkiness, deformed capitulum, poor seed set and lower seed yield. It has been reported that boron is also required for pollen germination and pollen tube growth [8], and boron deficiency at flowering can affect pollen viability and abortion of stamens and pistils [9-12] which contributes to low seed set. The boron requirement of many plants during reproductive growth is reputedly much higher than during vegetative growth $[13,14]$, a finding recently demonstrated in sunflower [5]. The functional boron in planta has been associated with water availability, sugar translocation, cation and anion absorption, and metabolism of N, P, carbohydrate, 
and fat [15]. Sunflower, has been found to be particularly sensitive to boron deficiency and is sometimes used as an indicator for assessing available boron in soils [14]. Although Boron is essential for crop growth and can be applied to meet crop demands, harmful effects can be induced by excessive applications during early phases of growth $[14,15]$. Yield and the component vegetative and reproductive stages of sunflower may both be affected both positively and negatively by boron depending upon the dose used as a fertilizer. To date very few studies have addressed the effectiveness of different minerals on the pollination of sunflower and the influence of optimum boron concentration on confection sunflowers has not been reported. The major objective of the present study was to evaluate the effect of yield characters of different concentrations of foliar boron applied boron before flowering.

\section{Materials and Methods}

Field trials using a randomized complete block design with three replications were conducted during both spring and autumn seasons (2009) at the gardens of the biology department, College of Science for Women, Baghdad University, to study the effect on yield of boron foliar fertilizer on an open pollinated sunflower cultivar (Shumoss). The soil type was a sandy loam (Table 1). Sowing dates were the 10th March and 7 th July in plots measuring $3 \times 3 \mathrm{~m}$ with four rows with an interrow distance of $75 \mathrm{~cm}$ and within row distance of $20 \mathrm{~cm}$ to reach an optimum population density of 71,500 plants ha ${ }^{-1}$ [16]. The amount of nutrient applied was $400 \mathrm{~kg}$ $\mathrm{N}$ ha ${ }^{-1}$ as urea and $280 \mathrm{~kg}_{2} \mathrm{O}_{5} \mathrm{ha}^{-1}$ as superphosphate. Boron was applied at six concentrations $(0,50,100,150$, 200, $\left.250 \mathrm{mg} \mathrm{L}^{-1}\right)$ as boric acid $\left(\mathrm{H}_{3} \mathrm{BO}_{3}\right)$. The plants were sprayed manually at the beginning of flowering during the early morning with 15 litres per plot $\left(1.67 \mathrm{~L} \mathrm{~m}^{-2}\right)$. Nitrogen was applied in 2 split doses. Hoe weeding and irrigation were carried out as needed. Ten plants from each plot were covered with polyethylene bags after flowering to protect them from bird attack at full maturity and these plants were subsequently used for full destructive analysis. Plants were harvested when the periphery of the flower head was a brown colour and its back was yellow to brown and felt hard with its head bent down and the petals wilted, and dry matter was measured on three plants per plot. Seed separation from sunflower heads was performed manually and air dried. Moisture content was measured using a digital moisture meter, and seed weights were corrected for all treatments to standard $8 \%$ moisture according to the international limit for seed storage of sunflower [16].

2.1. Measured Characters. The width $(L)$ of each green leaf per plant was measured after flowering was complete and the leaf area (LA) per plant calculated as follows, $\mathrm{LA}=0.56 \sum \mathrm{L}^{2}$ [17]. LAI was calculated from LA divided by the ground area per plant. Three harvested plants from each plot were cutup, put in paper bags and dried in an oven at $70^{\circ} \mathrm{C}$ for $48 \mathrm{~h}$, weighed [10], and then multiplied by the average population density to evaluate total dry matter $\left(\mathrm{t} \mathrm{ha}^{-1}\right)$. Head area was
TABLE 1: Soil characteristics.

\begin{tabular}{lcc}
\hline & Spring season & Autumn season \\
\hline Soil texture & Sandy loam & Sandy loam \\
pH & 8.1 & 7.93 \\
Electrical conductivity & 4.45 & 3.9 \\
$\left(\mathrm{mmhos} \mathrm{cm}^{-1}\right)$ & 28.2 & 22.4 \\
$\mathrm{~N}\left(\mathrm{mg} \mathrm{kg}^{-1}\right)$ & 15.33 & 14.2 \\
$\mathrm{P}\left(\mathrm{mg} \mathrm{kg}^{-1}\right)$ & 0.791 & 0.746 \\
$\mathrm{~K}\left(\mathrm{mg} \mathrm{kg}^{-1}\right)$ & 16 & 11 \\
$\mathrm{~B}\left(\mathrm{mg} \mathrm{kg}^{-1}\right)$ & 0.9 & 0.8 \\
O.M \% & &
\end{tabular}

calculated as: radius of head $* 3.14$ [16]. Seed separation from sunflower heads was performed manually and seed number counted. Weight of a random sample of 100 filled seed was corrected to $8 \%$ moisture after determination of seed moisture using a moisture meter. A random sample of $25 \mathrm{~g}$ of seed was taken from each treatment and visually examined to determine the full and empty seeds and the \% empty seed calculated. Seed yield $\left(\mathrm{t} \mathrm{ha}^{-1}\right)$ was estimated by multiplying the average plant yield after correction to $8 \%$ moisture multiplied by plant population density. Harvest index was calculated by dividing grain yield by total dry matter [18].

2.2. Statistical Analysis. The data collected were subjected to analysis of variance (ANOVA), and differences between means were evaluated using least significant differences (LSD) [19].

\section{Results}

3.1. Leaf Area (LA) $m^{2}$ and Leaf Area Index (LAI). LA and LAI are considered good surrogate measures of plant and crop photosynthesis which is an important factor of growth rate and eventual grain yield. There was a significant incremental effect of Boron on LA and LAI at both sowing dates (Figure 1). In the spring crop Boron and LA/LAI were related linearly (LA $\left.y=0.0294 x+0.4047, R^{2}=0.78\right),(\mathrm{LAI} y=$ $0.2103 x+2.8908, R^{2}=0.78$ ), and an increase of $1 \%$ of Boron concentration increased LA and LAI at the end of flowering by $0.4047 \%$ and $2.8908 \%$, respectively. Applications of 150 , 200 , and $250 \mathrm{mg} \mathrm{L}^{-1}$ resulted in significant increases of LA and LAI compared to the control. In the autumn crop the relationship between boron and LA, LAI was less clear and whilst 150,200 , and $250 \mathrm{mg} \mathrm{L}^{-1}$ boron significantly $(P<0.05)$ increased LA and LAI compared to the control, applications of 50 and $100 \mathrm{mg} \mathrm{L}^{-1}$ significantly $(P<0.05)$ decreased LA and LAI compared to the control.

3.2. Total Dry Matter $\left(t h a^{-1}\right)$ at Harvest. Dry matter was increased by increased application of boron (Figure 2). In the spring crop the effect of boron was a linear increase up to $150 \mathrm{mg} \mathrm{L}^{-1}$, but thereafter there was a linear decrease. Only the 100 and $150 \mathrm{mg} \mathrm{L}^{-1}$ application significantly increased dry matter compared to the control. In the autumn sowing 


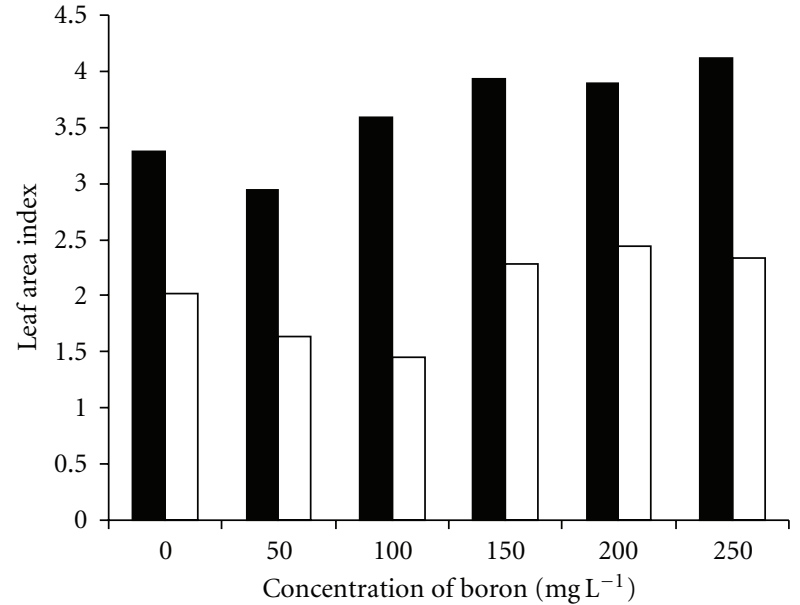

Figure 1: Effect of foliar applied boron on leaf area index (LAI) in spring (filled columns) and autumn (open columns) sunflower crops. ( $\mathrm{LSD}_{0.05} 0.420$ and 0.277 , resp.).

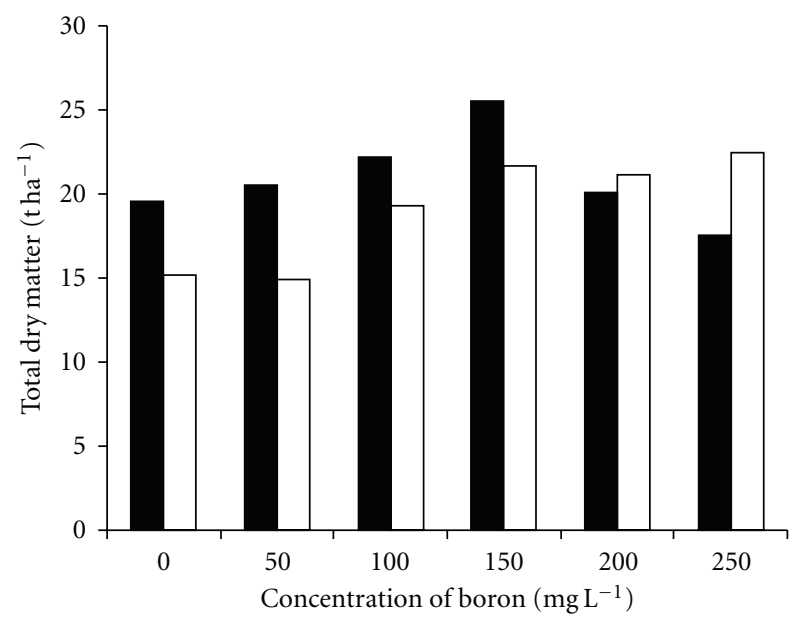

Figure 2: Effect of foliar applied boron on total dry matter ( $\mathrm{t} \mathrm{ha}^{-1}$ ) in spring (filled columns) and autumn (open columns) sunflower crops. $\left(\mathrm{LSD}_{0.05} 1.890\right.$ and 3.889 , resp.).

the relationship was linear $\left(y=1.6367 x+13.367, R^{2}=\right.$ 0.8531 ), and applications above $100 \mathrm{mg} \mathrm{L}^{-1}$ significantly increased dry matter compared to the control.

3.3. Head Area Characteristics. There were no significant differences of boron treatment on head area within sowing dates, but it was noted that heads on the spring plants were larger ( 300 to $400 \mathrm{~cm}^{2}$ ) than the autumn plants (250 to $300 \mathrm{~cm}^{2}$ ). The number of seeds per head was not affected to any great extent by boron applications with no significant differences in the spring crop. For the autumn crop 100, 200 and $250 \mathrm{mg} \mathrm{L}^{-1}$ significantly increased seed number compared to the control (Figure 3). Boron did not affect seed weight to any great extent, and there were no significant differences in the spring crop, and in the autumn crop only the $150 \mathrm{mg} \mathrm{L}^{-1}$ treatment increased seed weight significantly compared to the control (Figure 4).

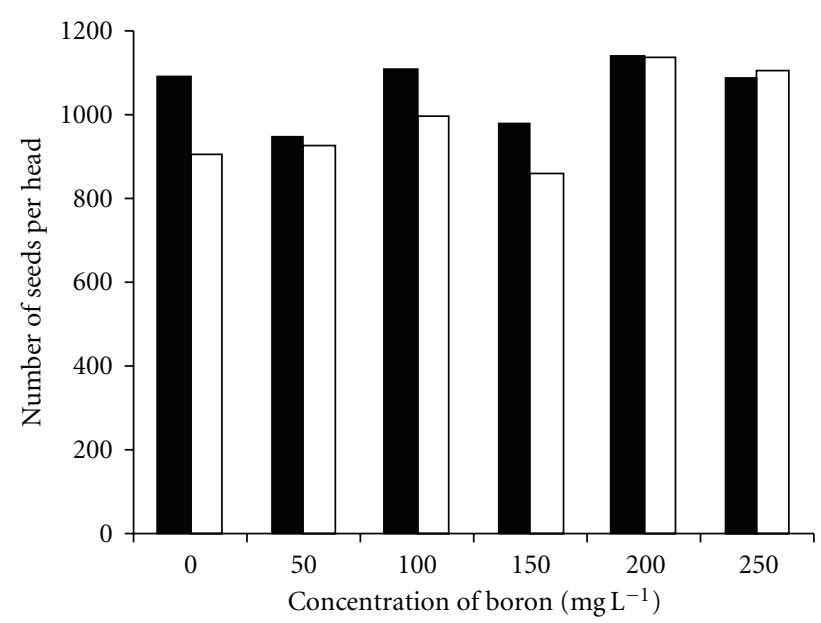

Figure 3: Effect of foliar applied boron on number of seed in head in spring (filled columns) and autumn (open columns) sunflower crops. ( $\mathrm{LSD}_{0.05} 124$ and 174, resp.).

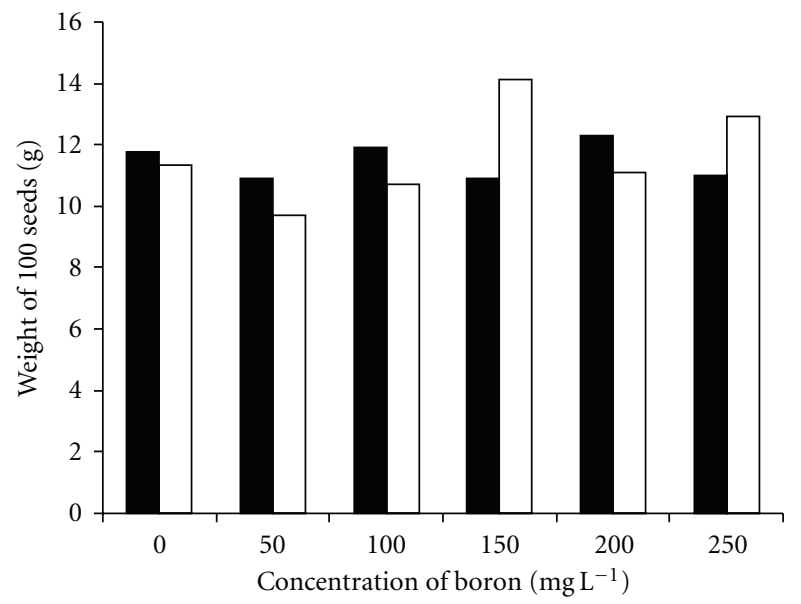

FIGURE 4: Effect of foliar applied boron on weight of 100 seed in spring (filled columns) and autumn (open columns) sunflower crops. ( $\mathrm{LSD}_{0.05} 1.075$ and 1.938 , resp.).

3.4. Empty Seed Percentage \%. Boron tended to decrease the empty seed percentage, and for the spring crop this was incremental and linear $\left(y=1.2709 x+17.257, R^{2}=0.9757\right)$ with applications above $150 \mathrm{mg} \mathrm{L}^{-1}$ leading to significant reductions in empty seed percentage compared to the control. For the autumn crop there was a trend for reduction in empty seed percentage above applications of $150 \mathrm{mg} \mathrm{L}^{-1}$, but these decreases were not statistically significant $(P>$ 0.05) (Figure 5).

3.5. Seed Yield $\left(t h a^{-1}\right)$. Seed yield increased linearly in the autumn crop $\left(y=0.6645 x+5.8777, R^{2}=0.8519\right)$ in response to boron, and 200 and $250 \mathrm{mg} \mathrm{L}^{-1}$ boron applications gave significant increases in yield compared to the control. In the spring crop the trend was not as clear, and only the $200 \mathrm{mg} \mathrm{L}^{-1}$ application gave any significant increase compared to the control (Figure 6). 


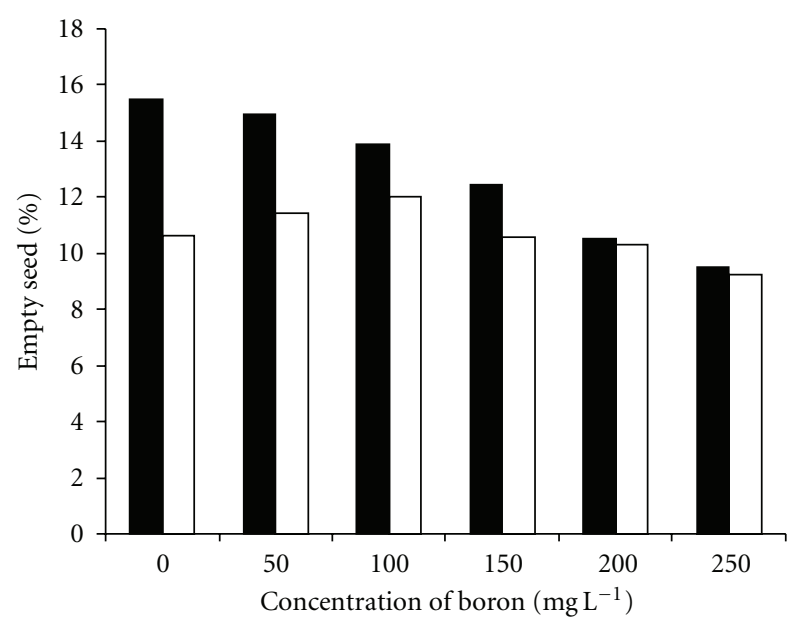

Figure 5: Effect of foliar applied boron on empty seed percentage $\%$ in spring (filled columns) and autumn (open columns) sunflower crops. (LSD $\mathrm{L}_{0.05} 1.6$ and N.S, resp.).

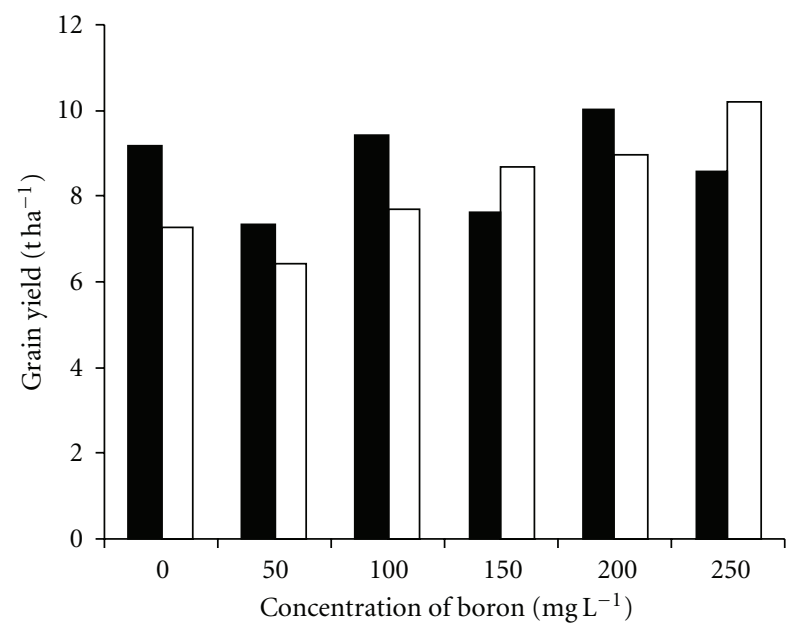

Figure 6: Effect of foliar applied boron on grain yield ( $\mathrm{t} \mathrm{ha}^{-1}$ ) in Spring (filled columns) and autumn (open columns) sunflower crops. ( $\mathrm{LSD}_{0.05} 0.738$ and 1.507 , resp.).

3.6. Harvest Index \%. There were no consistent effects on harvest index in response to boron, and differences were not significant compared with the control.

\section{Discussion}

The results of this experiment show clearly that boron fertilizer applied as a spray to sunflower plants at the beginning of flowering can have significant effects on seed set and seed yield. The boron was applied at the end of the vegetative stage, so it was not expected to have an effect on vegetative growth and development, but it clearly had a small but consistent effect on the green leaf area persistence at the end of flowering with higher levels of boron leading to greater LAI presumably through improved leaf area duration. This may be responsible for the consistent increased biomass that was measured. Seed yields also rose consistently with increases in boron application, and this may also be through a prolonged photosynthetic capacity during flowering and seed set or through improved partitioning from the increased biomass.

The biggest effect of applied boron was the increase in seed yield, and this is partly due to the decrease in seed sterility, a 5\% reduction in the spring crop, but also to small but incremental increases in seed size. The biggest measured effect was on biomass in the autumn crop which led to a consistent linear improvement in the seed yield. The results show that it is agronomically useful to apply boron to sunflower at the start of flowering, and more consistent effects are achieved at application levels of $1.67 \mathrm{~L} \mathrm{~m}^{-2}$ of 200 to $250 \mathrm{mg} \mathrm{L}^{-1}$ Boron.

\section{References}

[1] M. Charney, "Sunflower seeds and their products," Journal of Agricultural and Food Information, vol. 11, no. 2, pp. 81-89, 2010.

[2] A. Dag, E. Lior, and O. Afik, "Pollination of confection sunflowers (Heliantus annuus L.) by honey bees (Apis mellifera L.)," American Bee Journal, vol. 142, no. 6, pp. 443-445, 2002.

[3] F. P. Xanthopoulos, "Seed set and pollen tube growth in sunflower styles," Helia, vol. 14, pp. 69-72, 1991.

[4] Y. Vaknin, N. Barr, and Y. Saranga, "Preliminary investigations into the significance of floral applications of calcium, boron and polyphenols for increased seed set in confection sunflowers (Helianthus annuus L.)," Field Crops Research, vol. 107, no. 2, pp. 155-160, 2008.

[5] A. Asad, F. P. C. Blamey, and D. G. Edwards, "Dry matter production and boron concentrations of vegetative and reproductive tissues of canola and sunflower plants grown in nutrient solution," Plant and Soil, vol. 243, no. 2, pp. 243-252, 2002.

[6] A. Asad, F. P. C. Blamey, and D. G. Edwards, "Effects of boron foliar applications on vegetative and reproductive growth of sunflower," Annals of Botany, vol. 92, no. 4, pp. 565-570, 2003.

[7] B. S. Dear and R. G. Weir, Boron Deficiency in Pastures and Field Crops, Agfact.P1.AC.1, NSW Agriculture, 2nd edition, 2004.

[8] W. M. Dugger, "Boron in plant metabolism," in Encyclopedia of Plant Physiology, New Series 15 B, pp. 626-650, Springer, Berlin, Germany, 1983.

[9] C. Chitralekha and N. Nirmala, "Developmental aberrations in seeds of boron deficient sunflower and recovery," Journal of Plant Nutrition, vol. 23, no. 6, pp. 835-841, 2000.

[10] B. Dell and H. Longbin, "Physiological response of plants to low boron," Plant and Soil, vol. 193, no. 1-2, pp. 103-120, 1997.

[11] H. Xu, Q. Huang, K. Shen, and Z. Shen, "Anatomical studies on the effects of boron on the development of stamen and pistil of rape (Brassicanapus)," Acta Botanica Sinica, vol. 35, pp. 453-457, 1993.

[12] X. S. Zhang, Z. G. Shen, and K. Shen, "Effect of boron on floral organ development and seed setting of rapeseed," Acta Pedologica Sinica, vol. 31, pp. 146-152, 1994.

[13] F. P. C. Bamery, D. G. Edwards, and C. J. Asher, Nutritional Disorders of Sunflower, Department of Agriculture, University of Queensland, St. Lucia, Australia, 1987. 
[14] E. Y. Oyinlola, "Effect of boron fertilizer on yield and oil content of three sunflower cultivars in the Nigerian savanna," Journal of Agronomy, vol. 6, no. 3, pp. 421-426, 2007.

[15] V. M. Shorrocks, "The occurrence and correction of boron deficiency," Plant and Soil, vol. 193, no. 1-2, pp. 121-148, 1997.

[16] M. M. Al-Amery, Variations of growth and yield of the Zeamays and Helianthus annuus impact of genotype and plant density, M.S. thesis, Faculty of Agriculture, University of Baghdad, Baghdad, Iraq, 2001.

[17] M. M. Elsahooki and E. E. Eldabas, "One leaf dimension to estimate leaf area in sunflower," Journal of Agronomy and Crop Science, vol. 151, pp. 100-204, 1982.

[18] M. M. Elsahooki, Maize Production and Improvement, Ministry of Higher Education and Scientific Research. University of Baghdad, Baghdad, Iraq, 1990.

[19] R. G. D. Steel and Torrie, Principles and Procedures of Statistics, McGraw-Hill, New York, NY, USA, 1960. 


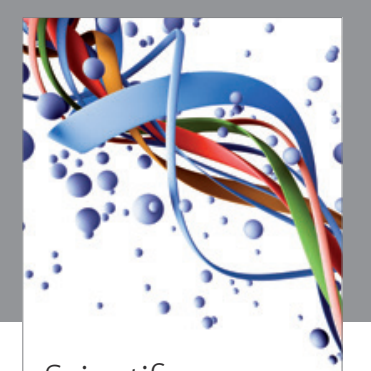

Scientifica
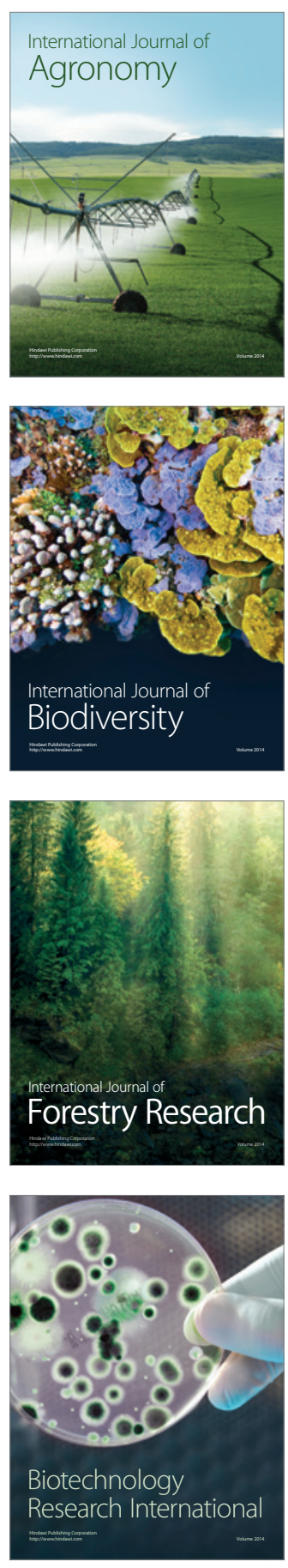
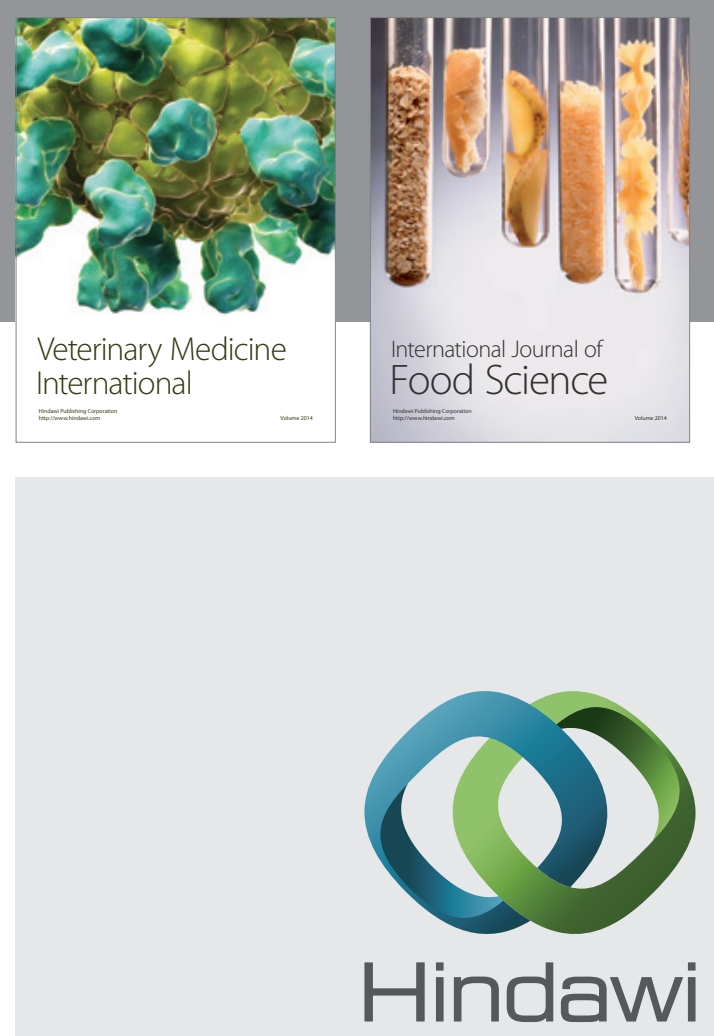

Submit your manuscripts at

http://www.hindawi.com
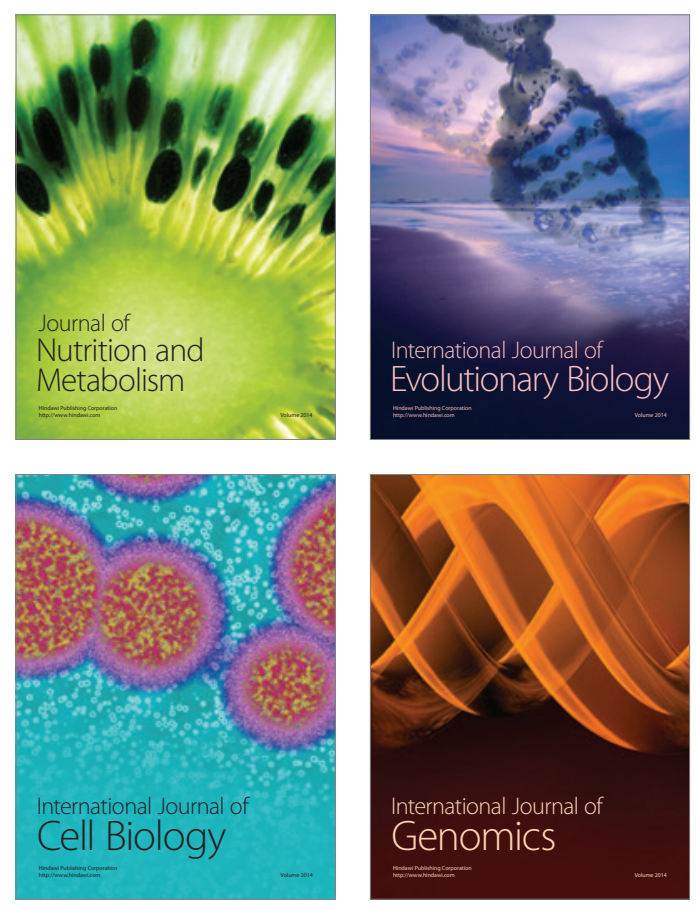
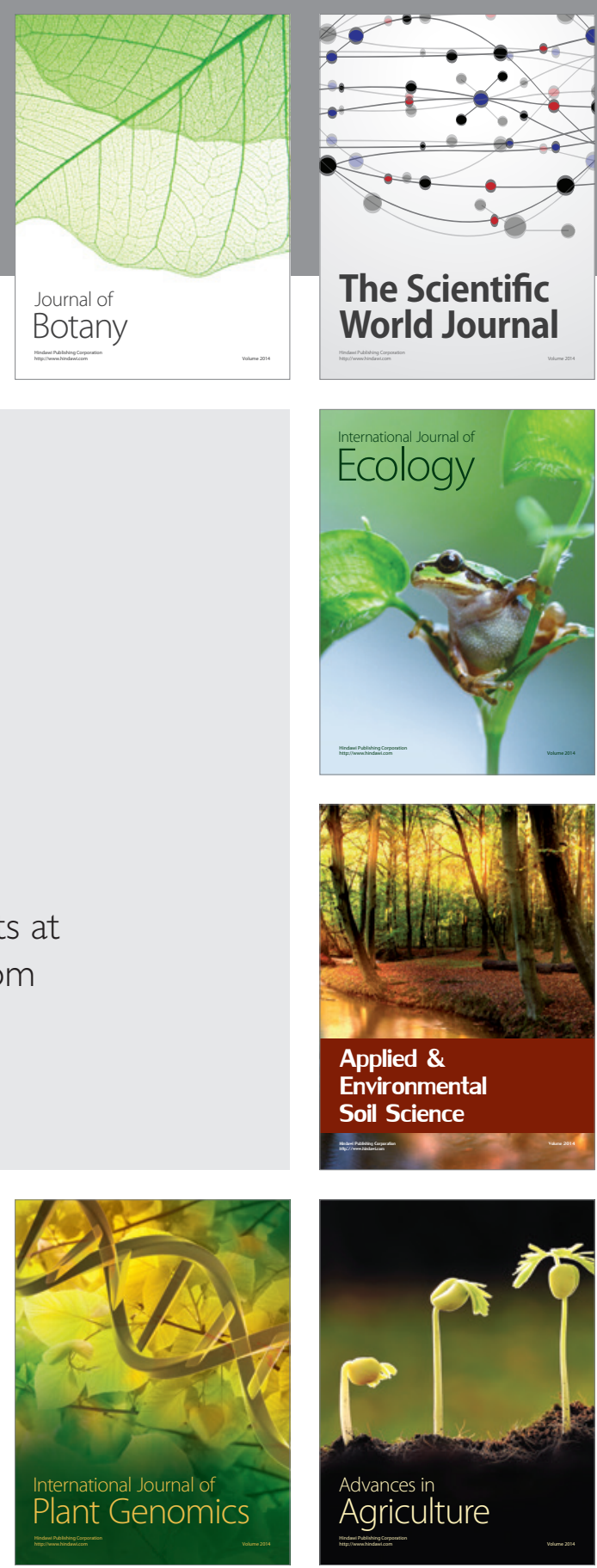

The Scientific World Journal
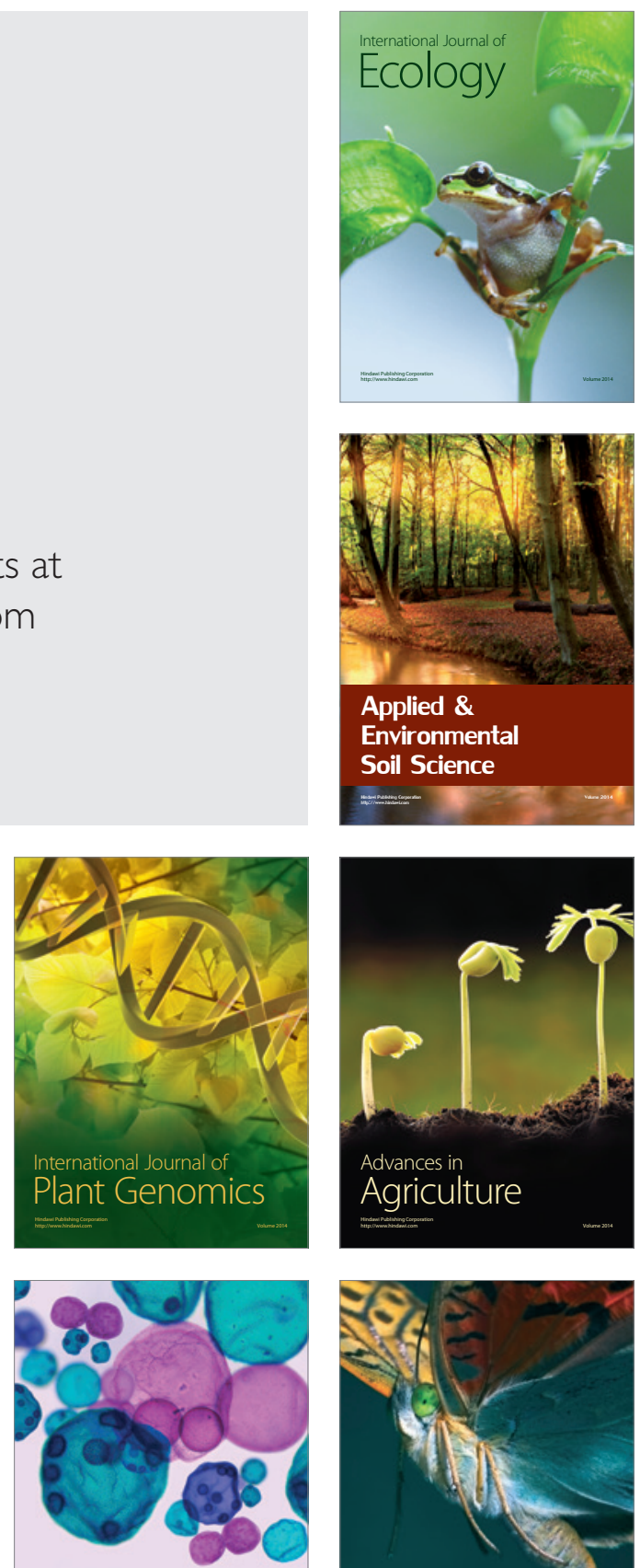

International Journal of Microbiology

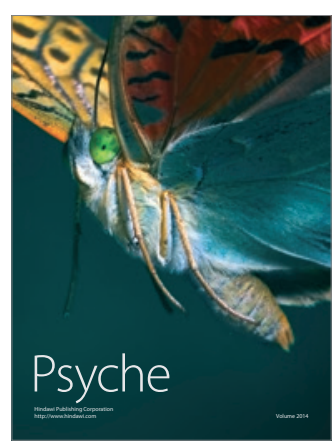

